\title{
UDC: 811.112.2
}

\section{АМБІВАЛЕНТНІСТЬ ПСИХОЛОГІЧНОЇ РЕАКЦЇ̈ В ОПОВІДАННІ ФРІДРІХА ДЮРРЕНМАТТА «ПІЛАТ»}

\author{
Людмила Комарніцька \\ Кандидат філологічних наук, викладач, \\ Кафедра соціальної роботи та психології, \\ Подільський спеціальний навчально-реабілітаційний \\ соціально-економічний коледж (УКРАЇ̈А), \\ 32300, Хмельницька область, м. Кам’янець-Подільський, вул. Годованця, 13, \\ e-mail: kob-1974@ukr.net
}

\begin{abstract}
PЕФЕРАТ
У статті аналізується оповідання Ф. Дюрренматта «Пілат», в якому за допомогою умовносимволічних, притчово-асоціативних форм (зокрема, через хронотоп зустрічі людини 3 Богом) автор здійснює оцінку сучасного богопокинутого стану людства крізь призму позачасових, універсальних цінностей. Метою статті є з'ясування своєрідності трансформації образу Понтія Пілата в оповіданні Ф. Дюрренматта і виявлення поетико-стильових особливостей художнього втілення психологічного стану людини в ситуації екзистенціальної кризи. Дослідницька методика грунтується на використанні структурно-функціонального, порівняльно-типологічного, культурно-історичного, контекстуального, герменевтичного, психоаналітичного методів. У результаті дослідження встановлено, що концептуальною домінантою образу Понтія Пілата в оповіданні Дюрренматта є думка про вічні й невідворотні помилки людини у iї стосунках із Вищою силою, невідповідність уявлень про Бога, а відтак i психологічної реакції на ситуацію екзистенціальної кризи. Твір є глибоко морально-філософським, що засвідчує сюжетна лінія про жорстоке поводження прокуратора з богом, його розп'яття та пізніше усвідомлення своєї провини. В оповіданні автор чітко акцентує увагу на проблему мотиву вини, яка перебуває у надто складному відношенні до мотиву страху, що домінує у творі. Амбівалентність психологічної реакції Понтія Пілата викликана амбівалентною позицією Бога, що спричиняє кризу у свідомості Пілата. Наукова новизна полягає у виявленні індивідуально-авторської стратегії переосмислення сюжету про Понтія Пілата як одного з продуктивних традиційних сюжетів у світовій літературі. Охарактеризовано потенційні чинники інтерпретації цього сюжету та їх вплив на варіанти трансформації традиційного матеріалу. Матеріал статті може бути використаний у процесі вивчення різних університетських курсів, у розробці вибіркових курсів філологічного спрямування у закладах вищої освіти, при підготовці підручників і посібників для середньої і вищої школи.
\end{abstract}

Ключові слова: Ф. Дюрренматт, Понтій Пілат, Бог, психологічна реакція, екзистенціальна криза.

\section{AMBIVALENCE OF THE PSYCHOLOGICAL REACTION IN THE STORY OF FRIEDRICH DURRENMATT «PILATE»}

\section{Liudmyla Komarnitska}

\author{
Ph.D. in Philology, Lecturer, \\ Department of Social Work and Psychology, \\ Podilskyi Special Educational-Rehabilitation Socio-Economic College (UKRAINE), \\ 32300, Khmelnytskyi region, Kamianets-Podilskyi, 13, Hodovantsia str., \\ E-mail: kob-1974@ukr.net
}

\begin{abstract}
The article analyzes the story of F. Durrenmatt's «Pilate», in which the author assesses the modern Godforsaken state of humanity through the prism of temporal, universal values, using conditionally symbolic, parableassociative forms (in particular, through the chronotope of the encounter of man with God). The purpose of the article is to find out the peculiarity of the transformation of Pontius Pilate's image in the story by F. Durrenmatt and to reveal the poetically stylistic features of the artistic embodiment of the psychological state of a person in a situation of existential crisis. The research methodology is based on the use of structural-functional, comparative-
\end{abstract}


typological, cultural-historical, contextual, hermeneutic, psychoanalytic methods. The study found that the conceptual dominance of the image of Pontius Pilate in the story of Durrenmatt is an opinion about the eternal and inevitable mistakes of a person in her relationship with the Higher power, about the inconsistency of the conception of God, and, consequently, the psychological reaction to the situation of the existential crisis. The work is deeply moral and philosophical, testifies to the plot rude cruel treatment of the prosecutor to God, his crucifixion and later awareness of his guilt. In the story, the author clearly focuses on the problem of the motive of guilt, which is too complicated with the motive of fear that dominates in the work. The ambivalence of the psychological answers of Pontius Pilate is caused by the ambivalent position of God, caused a crisis in the opinion of Pilate. The scientific novelty lies in the definition of an individual author's strategy of rethinking the history of Pontius Pilate as one of the most productive traditional objects in world literature. The potential factors of interpretation of this plot and their influence on the transformation options of traditional material are characterized. The material of the article can be used in the process of studying various university courses, in developing selective philology courses in higher educational institutions, in preparing textbooks and manuals for secondary and higher education.

Key words: F. Durrenmatt, Pontius Pilate, God, psychological reaction, existential crisis.

Однією з найважливіших тенденцій розвитку новітньої літератури, від помежів'я XIX i XX століть і аж дотепер, є активне звернення до традиційних сюжетів і образів та їх переосмислення відповідно до викликів сьогодення i творчих настанов авторів. Цей процес характеризується різноманітністю форм i способів письменницької роботи. Відтак і для сучасного літературознавства актуальним завданням є вивчення особливостей функціонування традиційного сюжетно-образного матеріалу різної генетичної природи. 3 давніх-давен привертає до себе увагу представників різних видів мистецтва і літератури, а також дослідників художньої творчості образ Понтія Пілата. Наразі ця сумнозвісна постать світової історії і культури зайняла особливе місце серед так званих вічних образів літератури. До образу Понтія Пілата й утілення його в різноманітних текстах неодноразово зверталися науковці, фахівці 3 культурології та історії літератури. Проблеми переосмислення та трансформації традиційних сюжетів і образів у літературі та пов'язаних із ними теоретиколітературних концепцій стали наріжними у працях Олександра та Олексія Веселовських, С. Аверінцева, В. Антофійчука, М. Бахтіна, С. Мелетинського, А. Волкова, Л. Грицик, Р. Гром'яка, В. Жирмунського, Д. Затонського, О. Лосєва, Ю. Лотмана, І. Мегели, С. Мелетинського, Д. Наливайка, І. Нєупокоєвої, А. Нямцу, О. Потебні, А. Діма, Д. Дюришина, Дж. Кемпбела, Н. Фрая, М. Еліаде та ін.

Віддаючи належне вже здійсненим дослідженням, тим не менше, маємо констатувати, що низка літературно-художніх творів, у яких образ Понтія Пілата відіграє ключову роль, поки що залишилась обійденою увагою дослідників. Необхідністю певною мірою заповнити цю прогалину зумовлюється актуальність пропонованої розвідки.

До творів, які вже самою своєю назвою пов'язані 3 євангельською традицією і безпосередньо орієнтовані на так званий Пілатовий комплекс, належить оповідання швейцарського лауреата Нобелівської премії Фрідріха Дюрренматта «Пілат». Воно було написане 1946 року й увійшло до збірки 3 дев’яти оповідань під загальною назвою «Місто», опублікованої 1952 року. Ці твори, як стверджують дослідники [5, с. 8], засвідчили суттєві зміни в світоглядно-естетичних поглядах письменника, що торкнулися і євангельської проблематики. 
Син протестантського пастора, Дюрренматт прекрасно знав біблійні тексти, однак ставлення до релігії загалом і до окремих євангельських тем упродовж його життя суттєво змінювалося. П. Бюлер, відомий знавець особистості й творчості Дюрренматта, з цього приводу зауважував: «Від своїх батьків він успадкував свідоме ставлення до релігії, від себе ж додав ще й частку критики. Під кінець життя він взагалі вважав за краще називати себе атеїстом, його позиція зазнала серйозної радикалізації внаслідок усе більш активного неприйняття будь-яких систем, ідеологій і фанатизму загалом» [2].

Оповідання «Пілат» повною мірою відображає істотні відмінності в трактуванні євангельської традиції Дюрренматтом, порівняно 3 іншими письменниками, хоча на поверхні тексту ми не побачимо ані очевидного розриву з відповідним каноном, ані технічних експериментів модерністського чи постмодерністського взірця. «Радикалізація» традиції, або в термінах компаративістики, переписування сюжету, торкається глибинних смислів аналізованого комплексу. Відтак, як будемо бачити, Пілат Дюрренматта - це зовсім не той римський правитель, жорстокий i безжальний, який хоч $\mathrm{i}$ співчував Ісусові, але не вагаючись відправив його на смерть.

Творчість Дюрренматта постійно привертає увагу літературознавців, однак оповідання «Пілат» зазвичай є периферійним предметом дослідження більш загальних тем. Показово, наприклад, що у монографії відомого російського фахівця зі швейцарської літератури Н. С. Павлової «Фридрих Дюрренматт» (Москва, 1967) цей твір навіть не згадується; одним реченням характеризує його й автор розлогої передмови до російськомовного п’ятитомника творів письменника В. Седельник (1997-1998). 3 українських літературознавців спеціально про оповідання «Пілат» писали А. Є. Нямцу [4], в контексті осмислення художньої присутності «Ісусового оточення» в «літературних євангеліях», а також 3.І. Кучер, яка присвятила даному творові невеликий фрагмент своєї дисертаційної праці «Особливості поетики та проблематика прози Ф. Дюрренматта» (Дніпропетровськ, 2003) [3].

Сюжет оповідання жорстко прив'язаний до ситуації суду Понтія Пілата над Ісусом, однак його змістовим стрижнем є мотив зустрічі з Богом та іiі наслідків для людини, яка неадекватно реагує на таку зустріч. Слід зазначити, що ім'я «Ісус» жодного разу в тексті не вживається, натомість слово «бог» пишеться 3 малої літери, що, вочевидь, підтверджує висловлену вище думку про неоднозначне ставлення письменника до християнської доктрини. 3 іншого боку, відмова від можливих прямих паралелей чи інтертекстуальних відсилань до євангельських текстів, навіть від усталених деталей даного сюжету (в оповіданні немає жодної згадки про первосвящеників, причин арешту підсудного, змісту його вчення; натомість вводяться «авторські» деталі, як-от у ситуації «умивання рук», коли прокуратор після цього закриває обличчя руками, «з яких ще капала вода») говорить про те, що у варіанті Дюрренматта Понтієвий сюжет більше скидається на притчу й асоціюється 3 недавніми подіями Другої світової війни, коли особиста відповідальність кожної людини за те, що відбувалося в світі, колосально зросла. Це тонко зауважив О. Звєрєв: ",Пілат" здається іносказанням, та він, звичайно, великою мірою і був спробою автора співвіднести трагічну сучасність із позачасовим, із універсальним, 
інакше кажучи, народився 3 поштовху, завжди визначального у притчовій літературі. Але він не залишився тільки алегоричною оповіддю про те, як, знову i знову вчиняючи зраду по відношенню до себе, людство потім розплачується за те, що поглумилося над власною природою i, подібно до заголовного героя, в жаху споглядає обличчя Бога, вбитого за погодженням із його волею...» [1]. Універсалізація змісту оповідання переводить його у формат екзистенціальної прози, для якої характерна екстремальність ситуації, гостре переживання персонажем свого психологічного стану як пограничного, на межі життя і смерті. Все це має місце в оповіданні Дюрренматта.

Жорстоке поводження прокуратора з богом, його розп’яття та пізніше усвідомлення своєї провини змушує й інших дослідників бачити в оповіданні насамперед морально-філософський зміст. Так, А. С. Нямцу вважає, що «...надзвичайно важливу роль в змістовній структурі оповідання Дюрренматта відіграє проблема особистої відповідальності індивідуума за свої вчинки. ... Очевидне прагнення Пілата перекласти частину свого знання і свою безумовну вину на цей натовп закінчується нищівною моральною поразкою персонажа...» [4, с.269]; «безвихідний трагізм стану прокуратора, його нездатність вийти за межі традиційної ролі: знаючи істину, він змушений піддавати Бога приниженням і тортурам - цього вимагає збожеволілий від спраги крові натовп - відправити його в кінцевому підсумку на Голгофу» [4, с. 269].

Про вину i «моральну загибель» Пілата пише також 3. І. Кучер, але констатує дещо інші домінанти: «3 жахом він чекає помсти, покарання. Втім, філософською домінантою в оповіданні «Пілат» $є$ питання змісту людських уявлень про Всевишнього. Саме очікування духовного підкорення, приховане бажання бачити в божественному силу, яка позбавляє від вибору та відповідальності за свої вчинки, і приводить Пілата до моральної загибелі...» $[3$, с. 12].

Безперечно, проблема вини чітко акцентована автором, однак мотив вини перебуває у надто складному відношенні до мотиву страху, який є явно домінуючим у творі. Так, у тексті твору слово «страх» та похідні від нього вживаються 11 разів (врахуємо ще й «жах», який зустрічається 5 разів), а слово «вина» - 4 рази. Страх, який відчуває прокуратор від самого першого погляду на бога, має скоріше не власне морально-психологічну, екзистенціальну природу.

Зустріч із Богом завжди таїть у собі небезпеку, і прокуратор, вперше глянувши на того, кого привели до нього на суд, відразу усвідомив, що перед ним Бог, і його не лише охопив непідконтрольний і неусвідомлюваний у своїх причинах страх («він не наважився навіть удруге глянути на нього, так йому стало страшно. Уникаючи дивитися в обличчя бога, він розраховував також виграти час, за який якось зуміє розібратися, пристосуватися до свого жахливого становища...» [1, с. 66]), а ще й усвідомлення своєї вибраності, відміченості: «Йому було ясно, що цим явленням бога він відзначений серед всіх людей, не закривав він очей і на небезпеку, яка неминуче містилася в такому відзначенні...» Далі прокуратор рефлексує головним чином з приводу того, як його сприймає бог (порівн.: «Для Пілата здавалося найважливішим дізнатися, як сприйняв бог його власну поведінку...»). Ситуацію ускладнює те, 
що Пілат не знає, як йому діяти, коли бог не виявляє своєї божественної природи, більше того - постає перед ним у найжалюгідніших проявах суто людського. В вигляді бога прокуратор бачить лише людське: «він побачив лише ці очі, і більше нічого. То були всього навсього людські очі, без всякої надлюдської сили або того особливого світла, яке захоплювало Пілата на грецьких зображеннях богів. I не було в них презирства, яке мають до людей боги, коли вони спускаються на землю, щоб винищити цілі покоління, але не було й непокори, яка жевріла в очах злочинців, яких приводять до нього на суд, - бунтівників, повстанців проти імперії, і дурнів, що вмирали сміючись...» $[1, \mathrm{c}$. 70]. Пілат підозрює, що такий вигляд бога, його безумовна покора $є$ підступним лицедійством, яким стирається грань між богом і людиною: «бог ставав людиною, а людина - богом».

«Амбівалентність психологічної реакції» Понтія Пілата, яку відзначає А. Є. Нямцу, насправді викликана амбівалентною позицією Бога, що й спричиняє кризу у свідомості Пілата. Він страждає через те, що бог зносить приниження, терпить немилосердні знущання й тортури, відчуває, як видно по його тілу, страшний біль, але не зупиняє цього, як міг би й повинен був зробити, з погляду смертної людини, всемогутній і безсмертний Бог. Відтак Пілат уважає, що Бог, прийнявши людську подобу, вдається до уловки, щоб випробувати все людство, а обрав для цього саме його. Прокуратор переконаний, що випробування продовжується й тоді, коли суд було закінчено i злочинця під тягарем хреста на плечах відправили до місця страти (зауважимо, що Голгофа в тексті також не згадується). Пілат очікує повідомлення про те, що Бог воскрес. В цей час щось надзвичайне починає діятися в природі і серед людей: «Сонце померкло. Небо перетворилося на камінь, і всі, хто був тут, здригнулися. Музиканти відібрали флейти від побілілих губ і, витріщивши очі, втупилися на загратовані вікна. Посеред неба нерухомо стояло мертве сонце, диск, позбавлений блиску і світла, подібний до величезної кулі, вкритої глибокими дірками. I тут затряслася земля, так що все попадало, і люди 3 криками втиснулися в землю...» $[1$, с. 70]. По дорозі до пагорбів, де були підняті хрести, Пілат бачить понівечених тварин, натовпи прокажених, тіла численних самовбивць. Прокурор очікує побачити пустий хрест, але, на превеликий його подив, його очам відкрилося змучене від страждань понівечено тіло з руками, відчайдушно простертими до неба. Прикметно, що наратор далі не передає нам реакції Пілата, а відразу переходить до того, що відбулося через три дні, коли прокураторові повідомили, що Бог «покинув свій гроб». Передчуття Пілата таки збулося: Бог воскрес, але він не покарав того, хто причинив йому стільки страждань, фізично, як того очікував кат, а залишив його в стані повного духовного змертвіння. Для посилення художнього ефекту автор в останній сцені оповідання відмовляється від проникнення у внутрішній світ протагоніста, натомість дає читачеві можливість побачити його зовні, очима раба, який супроводжує прокуратора, і в тому, що йому відкривається, наочно оприявнюються наслідки зустрічі людини з Богом, відмови від його відкритого визнання: «Неначе безкрайній ландшафт царства мертвих розстелили перед рабом - таким було це обличчя, бліде в світлі вранішнього 
дня, зі стуленими повіками, а коли очі повелителя відкрилися, погляд їх був холодним і байдужим...» $[1$, с. 76$]$.

Оповідання Дюрренматта одним із перших у повоєнній літературі відкрило й нові наративні стратегії в художніх трансформаціях євангельських подій, зокрема відтворення їх очима тих чи тих учасників цих подій. Розповідь у ньому ведеться від третьої особи (у цьому сенсі не зовсім точною є заувага А.Є. Нямцу: «в «Пілаті» Ф. Дюрренматта про розп'яття Христа розповідає прокуратор» [4, с. 247]), але організована вона в такий спосіб, що читачеві дається лише те, що бачить, відчуває, переживає головний герой. Ця так звана «персональна» розповідна ситуація (див.: [6, с. 110]) є не просто експериментом автора, а засобом залучення читача, створення враження, ніби оповідь дійсно ведеться від імені персонажа, а відтак посилення ефекту достовірності й донесення до читача авторської інтенції шляхом сугестивного навіювання.

Певним чином цю функцію виконує епіграф до тексту: «А Він відказав: Вам дано пізнати таємниці Божого Царства, а іншим у притчах, щоб дивились вони і не бачили, слухали і не розуміли» (Лк, 8:10) [1, с. 66]. Це один iз нечисленних прямих інтертекстуальних зв'язків твору із його претекстом, i після прочитання твору в епіграфі відкривається додатковий смисл: людина бачить і чує Бога, але не розуміє його, і в цьому полягає їі трагічна провина.

Важливою поетико-стильовою особливістю оповідання Дюрренматта $є$ те, що, попри свою очевидну філософську змістову домінанту і притчову спрямованість проблематики, весь текст твору напрочуд щільно насичений деталями предметно-художньої зображальності. Причому вони явно не мають історико-побутового функціонального призначення, а скоріше орієнтовані на експресивну візуалізацію, а відтак на посилення читацького сприйняття, на включення його в описувану ситуацію. До прикладу, згадаймо деталь, яка відсутня в Свангеліях (більша частина яких, за винятком хіба Євангелія від Івана, також сповнена предметної деталізації): Пілат, повертаючись, мало не налетів на дитину якогось раба, яка, плачучи, бігла через двір туди, «де під аркою воріт зник бог».

Таким чином, концептуальною домінантою образу Понтія Пілата в оповіданні Дюрренматта є думка про вічні й невідворотні помилки людини у іiі стосунках із Вищою силою, невідповідність уявлень про Бога, а відтак i психологічної реакції на ситуацію екзистенціальної кризи. Твір є глибоко морально-філософським, що засвідчує сюжетна лінія про жорстоке поводження прокуратора з богом, його розп'яття та пізніше усвідомлення своєї провини. В оповіданні автор чітко акцентує увагу на проблему мотиву вини, яка перебуває у надто складному відношенні до мотиву страху, що домінує у творі. Амбівалентність психологічної реакції Понтія Пілата викликана амбівалентною позицією Бога, що спричиняє кризу у свідомості Пілата.

\section{ЛІТЕРАТУРА}

1. Дюрренматт Ф. Пилат. Собр. соч.: в 5 т. Москва : Худож. лит., 1997. Т. 1. С. 66-76.

2. Eichenberger I. Dürrenmatt: «I paint because I think». URL: https://www.swissinfo.ch/eng/yearof-duerrenmatt_duerrenmatt---i-paint-because-i-think-/41631974 (дата звернення: 01.02.2020).

3. Кучер 3. І. Особливості поетики та проблематика прози Ф. Дюрренматта: автореф. дис. ... канд. філол. наук : 10.01.04. Дніпропетровськ, 2003. 20 с. 
4. Нямцу А. Миф. Легенда. Литература (теоретические аспекты функционирования). Черновцы : Рута, 2007. 520 с.

5. Седельник В. Д. Парадоксы и предостережения Фридриха Дюрренматта. Дюрренматт Ф. Собр. соч.: в 5 m. Москва : Художественная литература, 1997. . Т. 1. С. 5-24.

6. Шмид В. Нарратология. Москва : Языки славянской культуры, 2003. 312 с.

\section{REFERENCES}

1. Diurrenmatt, F. (1997), "Pilate", Selectes works in 5 vol. Vol. 1 ["Pylat", Sobranie sochynenyi v 5 t. T. 1], Khudozh. lit., Moscow, pp. 66-76. (in Russian).

2. Eichenberger, I. Dürrenmatt: "I paint because I think", available at: https://www.swissinfo.ch/eng/year-of-duerrenmatt_duerrenmatt---i-paint-because-i-think141631974. (in English).

3. Kucher, Z.I. (2003), The features of poetics and the problems of prose by F. Durrenmatt: Author's thesis [Osoblyvosti poetyky ta problematyka prozy F.Diurrenmatta: avtoref. dys. ... kand. filol. nauk], Dnipropetrovsk, 20 p. (in Ukrainian).

4. Niamtsu, A. (2007), Myth. Legend. Literature (theoretical aspects of functioning) [Myf. Lehenda. Lyteratura (teoretycheskye aspektbl funktsyonyrovanyia)], Ruta, Chernovtsy, 520 p. (in Russian).

5. Sedelnyk, V.D. (1997), "The paradoxes and warnings of Friedrich Durrenmatt", Diurrenmatt, F., Selectes works in 5 vol. Vol. 1. ["Paradoksы y predosterezhenyia Frydrykha Diurrenmatta", Diurrenmatt, F., Sobranie sochynenyi v 5 t. T. 1], Khudozh. lit., Moscow, pp. 5-24. (in Russian).

6. Shmyd, V. (2003), Narratology [Narratolohyia], Yazyiki slavyanskoy kulturyi, Moscow, 312 p. (in Russian). 